\title{
Growth Optimization of Glyphosate-based Herbicides Utilizing Bacteria isolated from Lotic Water of Ogini Stream, Nigeria
}

\author{
R. E. Aso, C. Hammuel, M. Daji, and J. Briska
}

\section{ABSTRACT}

Glyphosate-based herbicides are often used for the control of weeds grown on agricultural fields or farms. Different health problems have been reported to be associated with the use of glyphosate-based herbicides mainly due to their toxicity level. Thus, finding glyphosate utilizing microorganisms to remediate the glyphosate-based herbicides in the environment is crucial. The culture conditions for maximum utilization of glyphosate by bacterial isolates, Stenotrophomonas maltophilia, Bacillus cereus and Enterobacter aerogenes previously isolated from Ugini stream close to corn fields treated with glyphosate-based herbicide at Ofagbe, Delta State, Nigeria were optimized using mineral salt medium containing glyphosate as carbon source. The varied culture parameters assessed were temperature $\left(30,37\right.$ and $\left.40{ }^{\circ} \mathrm{C}\right), \mathrm{pH}(5,6,7,8$ and 9), initial glyphosate concentration $(1,3,5,7$ and $9 \mathrm{~g} / \mathrm{L})$ and incubation time (2-14 days). Optical density (OD) at $560 \mathrm{~nm}$ of the culture was used to estimate cell growth or cell load of the glyphosate utilizing bacteria strains at every 2 days for 14 days. The following optimal conditions were determined: initial $\mathbf{p H ~ 9 . 0 ,}$ incubation temperature $30{ }^{\circ} \mathrm{C}$, initial concentration of glyphosate $(1 \mathrm{~g} / \mathrm{L})$ and incubation time of 12 days. Of the isolates on the medium containing the herbicide as sole carbon and energy source, Bacillus cereus showed the highest growth level (OD average, $0.127, \mathrm{pH}$ average, 6.26. This was followed by Stenotrophomonas maltophilia $(\mathrm{OD}$ average $=0.114, \mathrm{pH}$ average $=6.44)$ and Enterobacter aerogenes $(\mathrm{OD}$ average $=0.100, \mathrm{pH}$ average, 6.56). At the increased of glyphosate in the medium there was decreased in growth of the bacteria. Bacillus cereus, Stenotrophomonas maltophilia and Enterobacter aerogenes indicated a high capacity to be able to degrade glyphosate. It is therefore concluded that the bacteria employed in this research can be recommended for bioremediation of environments contaminated with this chemical and further research should conducted to ascertain the catabolic genes present in these individual glyphosate degrading bacteria.

Keywords: cultivation conditions, glyphosate-degrading bacteria, optimization, water pollution.
Published Online: November 06, 2021

ISSN: 2684-5199

DOI : $10.24018 /$ ejbio.2021.2.6.290

\section{R. E. Aso*}

Department of Microbiology, Federal University Wukari, Nigeria.

(e-mail: rufoxaso@yahoo.com)

C. Hammuel

Department of Microbiology, Federal University Wukari, Nigeria.

M. Daji

Department of Microbiology, Federal University Wukari, Nigeria.

J. Briska

Department of Microbiology, Federal

University Wukari, Nigeria.

\section{*Corresponding Author}

\section{INTRODUCTION}

In many nations of the world, humans rely on surface freshwater for drinking, recreational purposes, and sources of foods of economic interest [1]. Bodies of water have been subjected to increasing pressure resulting from human activities, including contamination by a variety of inorganic and organic pollutants from farmlands as farm inputs which are usually washed into bodies of water and accumulate to the detriment of aquatic lives as reported by Shushkova et al. [2]. Most of these organic pollutants are herbicides [3], The common herbicides used on farmlands for agricultural purposes are 2, 4-dicholorophenoxyacetic acid (2, 4-D) and Roundup ${ }^{\circledR}$ (isoproplyamine salt of glyphosate). Most of the pesticides routinely and commonly used globally are glyphosate-based compounds which include Roundup ${ }^{\circledR}$, Accord $\AA$, Forceup ${ }^{\circledR}$ and Touchdown ${ }^{\circledR}[4]$. Glyphosate has a wide range of activity and is a non-selective herbicide for controlling and/or killing of grasses, herbaceous plants, including perennial weeds, and some shrubs [5]-[7]. The herbicides can find their way to the aquatic ecosystems through runoffs from agricultural farms [8].

Since glyphosate can easily be biodegraded by soil microorganisms and is usually absorbed by soil particles it is therefore assumed to be safe in the environment [5]. The main degradation pathway appears to involve the breaking down of $\mathrm{C}-\mathrm{N}$ bond of the herbicides (glyphosate) to produce aminomethyl phosphonic acid (AMPA) [15]. Glyphosate in a certain amount is usually washed away from farmlands to freshwater ecosystems despite being degraded by soil microorganisms. In freshwater ecosystems, the herbicide can be use up by microbial community, the same microbial biodegradation as in the soil. Some are absorption into sediments with the subsequent microbial breakdown of bound residues under anaerobic conditions [9]. Once glyphosate enters into a body of water the degradation occurs slowly, 
because aquatic environment contains fewer microorganisms than soil. Glyphosate and its main degradation product AMPA are among the most common pesticides detected in water-pollution [10].

Several bacterial strains have been associated with degradation of glyphosate [11]-[15], but most of these bacteria were isolated from soil environment. However, there are few reports on the isolation of bacteria from aquatic environment [16] and the comprehensive studies of the physiological regulation in bacterial cells are rather few [2]. Thus, the growth optimization of bacteria for degradation of these chemical pollutants is imperative for the physiological regulation, and the identification of these conditions will make it possible to know the factors that can be applied for bacteria in water or soil bioremediation.

The objective of this present study was to optimize some abiotic parameters for the cultivation of isolated strains (Stenotrophomonas maltophilia, Bacillus cereus and Enterobacter aerogenes), providing maximal effectiveness of the glyphosate degradation.

\section{MATERIALS AND METHODS}

\section{A. Source of Glyphosate Degrading Bacteria}

The three (3) glyphosate degrading bacteria (Stenotrophomonas maltophilia, Bacillus cereus and Enterobacter aerogenes) were isolated from Ugini stream close to corn fields treated with glyphosate-based herbicide at Ofagbe, Delta state of Nigeria [16] and maintained as part of culture collection in Microbiology Laboratory, University of Port Harcourt, Nigeria.

\section{B. Chemicals and Medium}

The glyphosate-based herbicide (in form of $480 \mathrm{~g} / \mathrm{L}$ isopropylamine salt) with commercial name "force up" was purchased from an agricultural chemical shop in Port Harcourt, Rivers State, Nigeria.

For the optimization using glyphosate as sole source of carbon and energy, modified mineral salts medium (MSM) of Ouided and Abderrahmane [17] was employed. The medium contain: $5.8 \mathrm{~g} \mathrm{~K}_{2} \mathrm{HPO}_{4} ; 4.5 \mathrm{~g} \mathrm{KH}_{2} \mathrm{PO}_{4} ; 2 \mathrm{~g}\left(\mathrm{NH}_{4}\right)_{2} \mathrm{SO}_{4} ; 0.16 \mathrm{~g}$ $\mathrm{MgCl}_{2} .2 \mathrm{H}_{2} \mathrm{O} ; 20 \mathrm{mg} \mathrm{CaCl}_{2} ; 2 \mathrm{mg} \mathrm{NaMoO}_{4} ; 1 \mathrm{mg}$ $\mathrm{FeSO}_{4} .7 \mathrm{H}_{2} \mathrm{O}$ and $1 \mathrm{mg} \mathrm{MnCl}_{2}$ per litre of deionized water. and $\mathrm{pH}$ was adjusted to 7.0. The basal medium was prepared and dispensed into $250 \mathrm{ml}$ Erlenmeyer flasks $(99 \mathrm{ml}$ per flask). To each of the flasks was added $1 \mathrm{ml}$ of glyphosate $(1 \mathrm{~g} / \mathrm{L})$. The mixture was autoclaved at $121^{\circ} \mathrm{C}$ for $15 \mathrm{~min}$ and allowed to cool. The experiment was performed in triplicate and each flask received $0.1 \mathrm{~mL}$ of a $24 \mathrm{~h}$ culture of each isolate tested. The fourth flask remained uninoculated and served as control. The flasks were incubated on a rotary shaker (Gallenkamp, England) at $120 \mathrm{rpm}$. Optical density (OD) at $560 \mathrm{~nm}$ using spectrophotometer (Spectronic 20, USA) was measured every 2 days for 14 days.

\section{Inoculum Preparation and Standardization}

Inocula that used for the study were prepared by inoculating the isolates in nutrient broth and incubated were at $30^{\circ} \mathrm{C}$ for $24 \mathrm{~h}$. With the aid of sterile normal saline, the 24 hour culture were suspended to 0.5 Macfarlane standards.
D. Effect of Incubation Time on the Growth of B. cereus,

\section{$S$. maltophilia and E. aerogenes in Glyphosate}

'The time course of growth of B. cereus, S. maltophilia and E. aerogenes were monitored for a period of 14days using the MSM enriched with glyphosate as sole carbon source as described by Moneke et al. [18].

$250 \mathrm{ml}$ Erlenmeyer flasks containing $99 \mathrm{ml}$ of the sterile screening medium was prepared and $1 \mathrm{ml}$ of "force-up" (containing $1 \mathrm{mg} / \mathrm{ml}$ of glyphosate) was added to each flask. $1 \mathrm{ml}$ of the inoculum (0.5 Macfarlane standards) of each selected isolate was used to inoculate each flask (experiments were carried out in 3 replicates). The three isolates used were selected based on their utilization patterns [16]. The medium was then incubated at $30^{\circ} \mathrm{C}$ for 14 days on a shaker incubator at $120 \mathrm{rpm} .5 \mathrm{ml}$ of the culture medium was collected from each flask at 2 days intervals and assayed for growth by measuring the optical density at $560 \mathrm{~nm}$ using a spectroptotometer.

\section{E. Optimization of Culture Parameters for Glyphosate Degradation}

Different culture parameters were considered in order to optimize growth in glyphosate enriched mineral salts medium. Some of the important culture parameters considered are temperature $\left(30,37\right.$ and $\left.40{ }^{\circ} \mathrm{C}\right), \mathrm{pH}(5.0,6.0$, $7.0,8.0$ and 9.0) and initial concentration of glyphosate $(1,3$, 5,7 and $9 \mathrm{~g} / \mathrm{L}$ ). The method of Ouided and Abderrahmane [17] was adopted. All experiments were performed in $250 \mathrm{~mL}$ flasks containing 99 millilitres of the mineral salt medium supplemented with an appropriate amount of glyphosate and was adjusted to an appropriate initial $\mathrm{pH}$ and inoculated with 1millilitre of Bacillus cereus, Enterobacter aerogenes and Stenotrophomonas maltophilia strains. The flasks were then incubated at the appropriate temperature for 12 days on a rotary shaker incubator at $120 \mathrm{rpm}$. Controls without inoculation were kept in similar conditions. Five millilitre of the culture medium was collected from each flask at two days intervals and assayed for growth by measuring the optical density at $560 \mathrm{~nm}$ using a spectrophotometer [17].

\section{RESULTS}

The effect of medium temperature on glyphosate degradation is shown in Fig. 1-3. Biodegradation of glyphosate was relatively greater at an incubation temperature of $30^{\circ} \mathrm{C}$ and $35^{\circ} \mathrm{C}$. With maximum degradation at $30{ }^{\circ} \mathrm{C}$ and minimum degradation at $40{ }^{\circ} \mathrm{C}$. The three bacterial strains all respondent similarly to change in temperature.

The effect of initial $\mathrm{pH}$ on glyphosate degradation is shown in Fig. 4. Glyphosate utilization by Stenotrophomonas maltophilia, Bacillus cereus and Enterobacter aerogenes was also investigated at different initial $\mathrm{pH}$ of broth culture (Fig. 4). All the three selected bacterial strains behave similarly for the glyphosate degradation in culture broths of different $\mathrm{pH}$. Alkaline $\mathrm{pH}$ was favourable for glyphosate utilization by the different selected bacterial strains. 


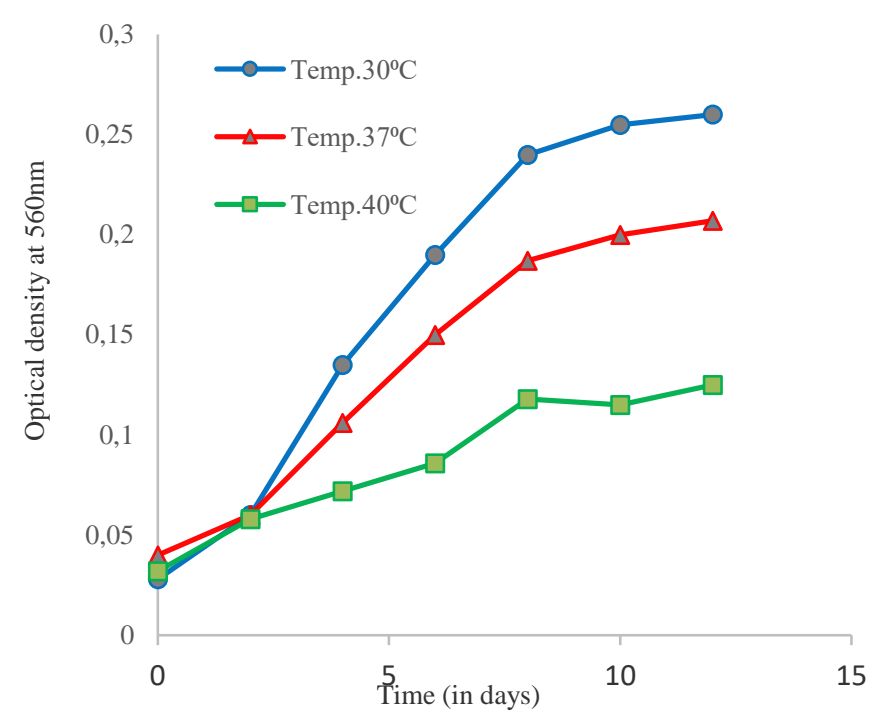

Fig. 1. Effect of incubation temperature on growth and glyphosate utilization by Bacillus cereus.

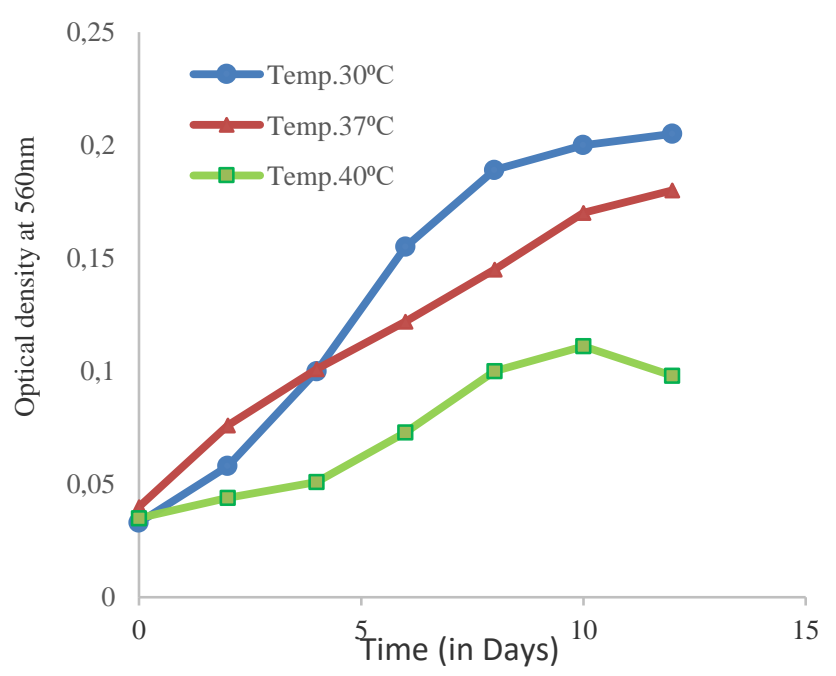

Fig. 2. Effect of incubation temperature on Growth and glyphosate utilization by Stenotrophomonas maltophilia.

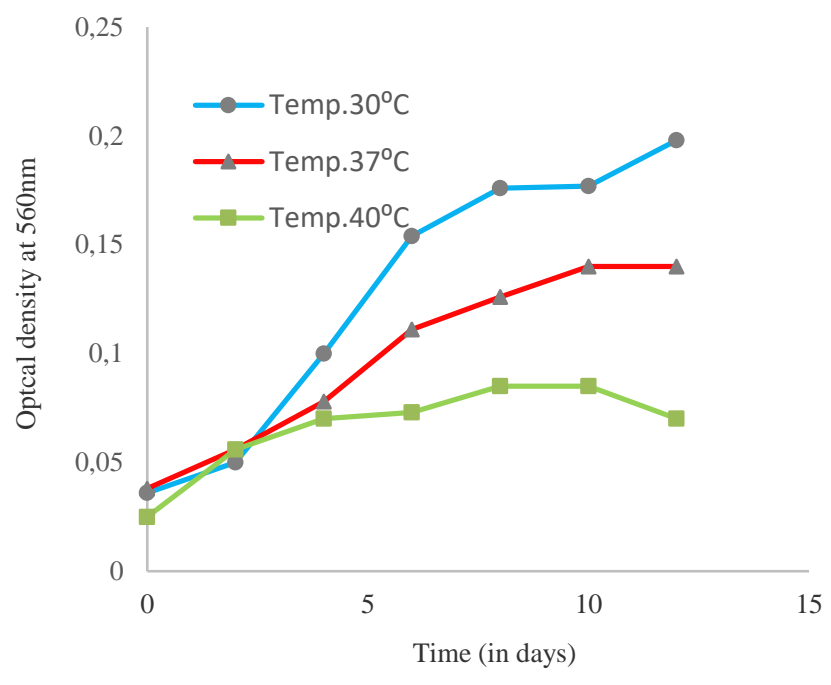

Fig. 3. Effect of incubation temperature on Growth and glyphosate utilization by Enterobacter aerogenes strain MDAZTIIIR 105a.

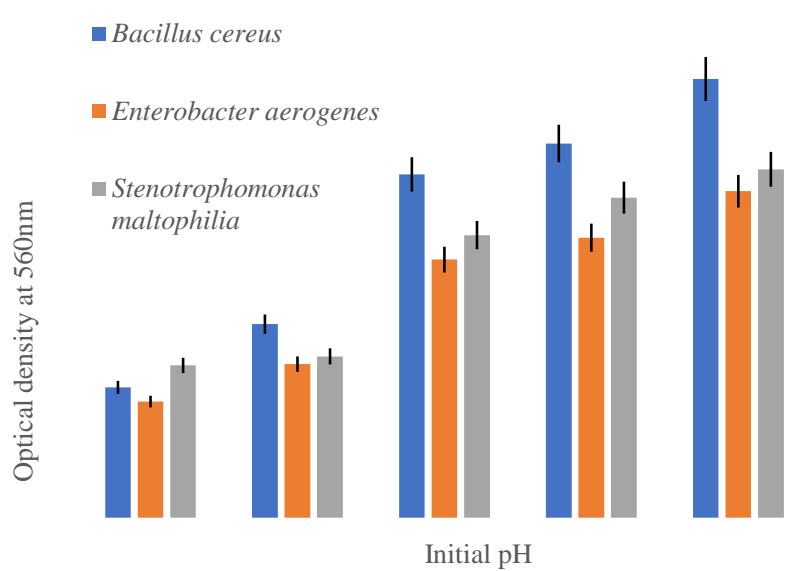

Fig. 4. Effect of $\mathrm{pH}$ on the growth and utilization of glyphosate by the different bacteria strains.

Effects of different initial glyphosate concentration on the degradation of glyphosate are shown in Fig. 5. As the concentration of glyphosate increased there was a corresponding decrease in the growth of the strains.

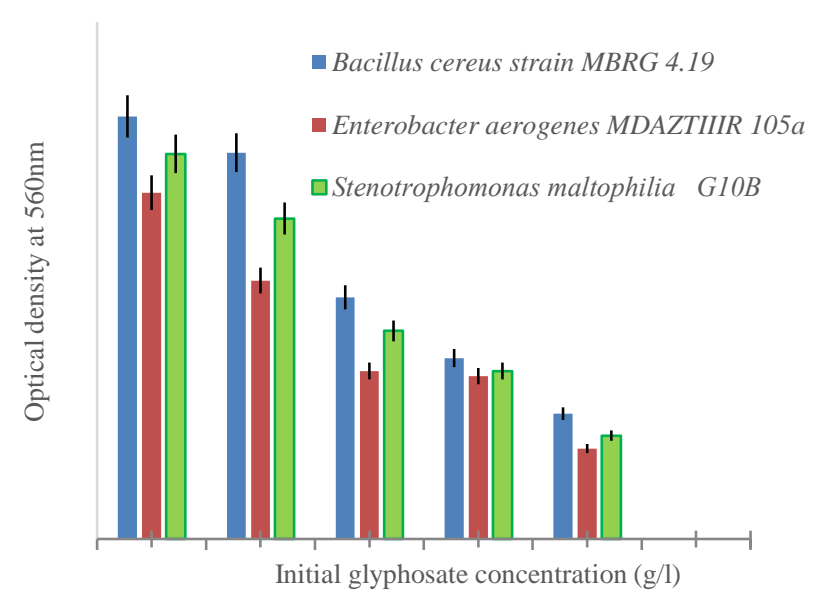

Fig. 5. Effect of the initial concentration of glyphosate on the growth of selected bacterial strains.

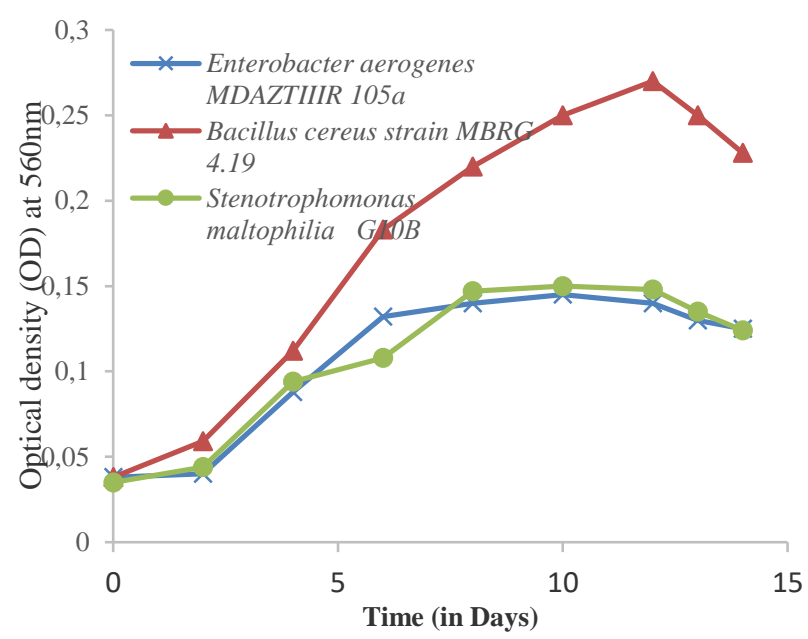

Fig. 6. Incubation time of the different glyphosate utilizing bacteria strains.

Effect of incubation period on the degradation of glyphosate is presented in Fig. 6. The growth of Bacillus cereus, Stenotrophomonas maltophilia and Enterobacter 
aerogenes were further monitored over time (14 days) at 560 $\mathrm{nm}$, using the MSM enriched with glyphosate as sole carbon source. The degradation rate increased constantly with the increase in time. The degradation of the herbicide started on the second day and increased rapidly to the sixth day except the degradation by Bacillus cereus with growth that continue rapidly to the $12^{\text {th }}$ day. The $12^{\text {th }}$ day was selected as the optimal degradation time.

\section{DisCUSSION}

The optimal temperature for the growth of Bacillus cereus, Stenotrophomonas maltophilia and Enterobacter aerogenes strain was $30{ }^{\circ} \mathrm{C}$. This could be possible because the key enzyme(s) responsible for glyphosate utilization can have their optimum enzymatic activity at $30{ }^{\circ} \mathrm{C}$ [19]. Better biodegradation of organophosphate pesticide at this temperature have also been described by Ouided and Abderrahmane, [17]. Moorman [20] also reported that, temperature used for incubation also affect the growth rate of bacterial strains.

With the maximum glyphosate utilization at $\mathrm{pH} 9.0$ and minimum at $\mathrm{pH}$ 5.0. Mostly, bacterial cultures prefer neutral to alkaline conditions for their normal growth that is why utilization at this $\mathrm{pH}$ ranges were at the maximum. Biodegradation of glyphosate at maximum $\mathrm{pH}$ value have also been described by earlier workers [21], [17]. The higher utilization of glyphosate at $\mathrm{pH} 9.0$ may be due to chemical hydrolysis.

The high concentrations of glyphosate severely inhibit bacterial growth [20]. The highest growth of the bacteria was observed at herbicide concentration of $1 \mathrm{~g} / \mathrm{L}$, which was the least tested concentration of the glyphosate. No inhibition of growth was observed when initial concentration was increased further, indicating that the isolates can tolerate up to $9 \mathrm{~g} / \mathrm{L}$ of glyphosate.

The increase in glyphosate concentration that led to a concomitant decrease in the growth of the isolates in this research is in contrast with the report of Amoros et al. [11], who observed and reported increase in Aeromonas count in increase in different concentrations (50 and $100 \mathrm{mg} / \mathrm{l})$. In this research, high cell density was recorded for the isolates at glyphosate concentrations of 1-3 g/L after 12 days of incubation at $30{ }^{\circ} \mathrm{C}$. However, at higher concentrations $(5,7$ and $9 \mathrm{~g} / \mathrm{L}$ ), the cell density was very low. Even though there was a severe decline in growth of the organisms occurred at high concentrations ( 7 and $9 \mathrm{~g} / \mathrm{L}$ ), the isolates were still able to tolerate $9 \mathrm{~g} / \mathrm{L}$ of glyphosate. This could be due to the presence of degradative systems, metabolic genes, or enzymes in the organisms. A similar research result was carried out by Moneke et al. [18] who in their research work tested different initial concentrations of glyphosate on Acetobacter sp. and $P$. fluorescens. Tolerance to high pesticide concentrations in this research work can be of great importance for the degradation of the pesticides since concentrations at contaminated sites may be several orders of magnitude higher than the recommended usage doses for these products.

From all parameters tested, it is highly likely that the different selected bacterial strains Bacillus cereus, Stenotrophomonas maltophilia and Enterobacter aerogenes strain could be employed for bioremediation of glyphosate contaminated soil, sediments, and ponds over a wide range of environmental conditions.

\section{CONCLUSION}

The glyphosate utilizing bacterial isolates including such Bacillus cereus, Stenotrophomonas maltophilia and Enterobacter aerogenes were optimized for tolerate the pesticide concentration at different parameters selected, it is therefore concluded that the selected bacterial strains could be employed for bioremediation of glyphosate contaminated soil, sediments and ponds over a wide range of environmental conditions.

\section{REFERENCES}

[1] M.A. Wilson, and S.R. Carpenter, "Economic valuation of Freshwater ecosystem services in the United States", Ecological Application. vol 9, pp. 772-783, 1999.

[2] T.V. Shushkova, I.T. Ermakova, A.V. Sviridov, A.A. Leontievsky, "Biodegradation of glyphosate by soil bacteria: Optimization of cultivation and the method for active biomass storage". Journal of Microbiology, 81:44-50, 2012.

[3] U. Dorigo, C. Leboulanger, A. Bérard, A. Bouchez, J.F. Humbert and B. Montuelle, "Lotic biofilm community structure and pesticide tolerance along a contamination gradient in a vineyard area". Aquatic Microbial Ecology, vol. 50, pp. 91-102, 2007.

[4] J.E. Franz, M.K. Mao, and J.A. Sikorski, "Glyphosate: A Unique Global Herbicide"; American Chemical Society: Washington, DC, USA, pp. 521-527, 1997.

[5] D.W. Kolpin, E.M. Thurman, E.A. Lee, M.T. Meyer, E.T. Furlong, and S.T. Glassmeyer, "Urban contributions of glyphosate and its degradate AMPA to streams in the United States". Environmental Science and Technology, vol. 354, pp. 191-197, 2006.

[6] A. Ghanem, P. Bados, A.R. Estaun, L.F. de Alencastro, S. Taibi, and J. Einhorn, "Concentrations and specific loads of glyphosate, diuron, atrazine, nonylphenol and metabolites thereof in French urban sewage sludge". Chemosphere, vol. 69 pp.1368-1373, 2007.

[7] F. Botta, G. Lavison, G. Couturier, F. Alliot, E. Moreau-Guigon, N Fauchon, B. Guery, M. Chevreuil, and H. Blanchoud, "Transfer of glyphosate and its degradate AMPA to surface waters through urban sewerage systems". Chemosphere. 77:133-139, 2009.

[8] A. Carter, "How pesticides get into water and proposed reduction measures". Pesticide Outlook, vol. 149, pp.15, 2000.

[9] E. Mallat, and D. Barceló, "Analysis and degradation study of glyphosate and of aminomethylphosphonic acid in natural waters by means of polymeric and ion- exchange solid-phase extraction columns followed by ion chromatography-post column derivatization with fluorescence detection". Journal of Chromatography, Vol. 823: 129136, 1998.

[10] E.A. Scribner, W.A. Battaglin, R.J. Gilliom, and M.T. Meyer, "Concentrations of glyphosate, its degradation product, aminomethylphosphonic acid, and glufosinate in ground- and surfacewater, rainfall, and soil samples collected in the United States", Scientific Investigations Report, U.S. Geological Survey, Reston, Virginia. pp 2007-5122, 2007.

[11] I. Amoros, J.L. Alonso, S. Romaguera, and J.M. Carrasco, "Assessment of Toxicity of Glyphosate-based Formulation Using Bacterial Systems in water". Chemosphere. vol. 67, pp. 2221-2228, 2007

[12] A. Obojska, N.G. Ternana, B. Lejczak, P. Kafarski, and P. McMullan, "Organophosphate utilization by the thermophile Geobacillus caldoxylosilyticus T20”. Applied and Environmental Microbiology. vol. 68, pp. 2081-2084, 2002

[13] R.H. Peng, Y.S. Tian, A.S. Xiong, W. Zhao, X.Y. Fu, H.J. Han, C. Chen, X.F. Jin, and Q.H. Yao, "A novel 5-enolpyruvylshikimate-3phosphate synthase from Rahnella aquatilis with significantly reduced glyphosate sensitivity". Journal of Biochemistry. 35: pp. 4199-210, 2012.

[14] C.M. Liu, P.A. McLean, C.C Sookdeo, and F.C. Cannon,"Degradation of the herbicide glyphosate by members of the family Rhizobiaceae". Archives of Microbiology, vol. 57, pp. 1799-1804. 
[15] Y.V. Kryuchkova, G.L. Burygin, N.E. Gogoleva, Y.V. Gogolev, M.P. "Chernyshova, O.E. Makarov, E.E. Fedorov, O.V. Turkovskaya, Isolation and characterization of a glyphosate-degrading Rhizosphere strain, Enterobacter cloacae K7". Journal of Microbiological Research. 13: 34-37.

[16] C.N. Ariole,P.O. Okerentugba, and R.E. Aso, "Isolation and molecular identification of glyphosate utilizing bacteria from lotic water". Nigerian Journal Microbiology, vol. 30 pp. 2999-3006, 2015.

[17] Ouided Benslama and Abderrahmane Boulahrouf, "solation and characterization of glyphosate-degrading bacteria from different soils of Algeria". Afr. J. Microbiol. Res. 7(49), pp. 5587-5595. 2013

[18] A.N. Moneke, G.N. Okpala, and C.U. Anyanwu, "Biodegradation of glyphosate herbicide in vitro using bacterial isolates from four rice fields". African Journal of Biotechnology. vol. 9, pp. 4067-4074, 2010.

[19] V. Patel, S. Cheturvedula, D. Madamwar, "Phenanthrene degradation by Pseudoxanthomonas sp. DMVP2 isolated from hydrocarbon contaminated sediment of Amlakhadi canal, Gujarat, India". Journal of Hazardous Materials, vol. 30, pp. 43-51, 2012.B. Ouided, and B. Abderrahmane, "Isolation and characterization of glyphosatedegrading bacteria from different soils of Algeria". African Journal of Microbiology Research, vol. 7, No. 49, pp. 5587-559, 2013.

[20] T.B. Moorman,"Pesticide degradation by soil microorganisms: environmental, ecological and management effects". Advances in Soil Sciences, vol. 33, pp. 261-165, 1994

[21] F. Jieyu, Y. Guoxia, Z. Haoyu, S. Guanying, G. Yucong, H. Taiping, and K. Tao, "Isolation, identification and characterization of a glyphosate-degrading bacterium, Bacillus cereus CB4, from soil". Journal of General and Applied Microbiology, vol. 58, pp. 263-271, 2012.

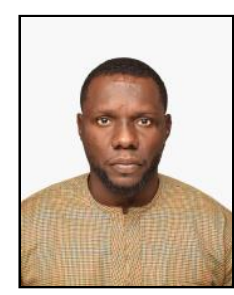

Aso R. E. hailed from Isoko North Local Government Area, Delta State, Nigeria. He had his first degree (B.Sc.) in Microbiology with a specialty in Environmental Microbiology, from the University of PortHarcourt, Rivers State, Nigeria in 2010 and his Master Degree (M.Sc.) in Environmental Microbiology and Bioremediation, from the University of PortHarcourt, Rivers State, Nigeria in 2015. Both degrees have accorded him professional mastery of Microbiology. $\mathrm{He}$ is proficient in public speaking, a team player, easy-going but firm, and a loyal person. He is Currently a PhD student at the University of Benin, Edo State, Nigeria. Where he is studying Environmental Microbiology and Public Health. He is a lecturer in the Department of Microbiology, Federal University Wukari, Taraba State, North East, Nigeria. His research interests span from Environmental bioremediation, waste-towealth, and public health. He has many scholarly publications in both international and local journals to his credit.

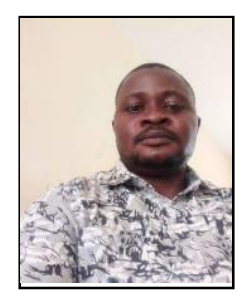

Dr. Hammuel C. is from Zing Local Government, Taraba State, Nigeria. He had his first degree (B. Tech.) in Microbiology at then Federal University now Modibo Adama University Yola in 2007. He proceeded to Ahmadu Bello University (ABU) Zaria, where he had his M. Sc. (Microbiology) in 2014, where he equally obtained his Doctor of Philosophy, Microbiology in 2021.

Dr. Hammuel C. started his job career in National Research Institute for Chemical Technology, Zaria. He rose from the position of Research Office II to the rank of Principal Research Officer from 2009 to 2019 with ten years unbroken research experience. He is currently a Lecturer in Federal University Wukari, Taraba State.

Dr. Hammuel C. is a registered member of Nigeria Society of Microbiology and has attended conferences and presented some conference papers. He has published over twenty scientific papers in some reputable journals. 